\title{
Peningkatan Pengetahuan Dan Partisipasi Mahasiswa Universitas Tanjungpura Sebagai Agen Perubahan Dalam Upaya Meningkatkan Penemuan Kasus TB Di Kota Pontianak
}

\section{Increasing Knowledge and Participation of Universitas Tanjungpura Studens as an Agent of Change in Efforts to Improve Case Detection of Tuberculosis Cases In Pontianak City}

Agus Fitriangga*

Departmen of Community Medicine, Faculty of Medicine Universitas Tanjungpura

Email : afitriangga@medical.untan.ac.id

\begin{abstract}
Abstrak
Tuberkulosis (TB) paru merupakan penyakit infeksi menular yang disebabkan oleh Mycobacterium tuberculosis. Insiden TB di Indonesia mencapai 842 ribu kasus dengan angka mortalitas 107 ribu kasus. Jumlah ini membuat Indonesia berada di urutan ketiga tertinggi untuk kasus TB setelah India dan China. Namun angka penemuan kasus TB di Kalimantan Barat belum mencapai target yang ditentukan yaitu 152 per 100.000 penduduk, bahkan cenderung mengalami penurunan. Tahun 2015 angka CNR adalah 120 per 100.000 dan tahun 2016 CNR menurun menjadi 103 per 100.000. untuk meningkatkan penemuan kasus TB di Kota Pontianak, perlu pelibatan unsur masyarakat, termasuk mahasiswa. Pelatihan ini bertujuan untuk meningkatkan pengetahuan mahasiswa Universitas Tanjungpura tentang penyakit TB sehingga diharapkan dapat menjadi agent bagi Dinas Kesehatan Kota Pontianak khususnya dalam deteksi kasus TB.
\end{abstract}

Kata Kunci : Tuberkulosis, mahasiswa, Universitas Tanjungpura, pelatihan, deteksi Kasus TB

\section{Abstract}

Pulmonary tuberculosis (TB) is a contagious infectious disease caused by Mycobacterium tuberculosis. TB incidence in Indonesia reached 842 thousand cases with a mortality rate of 107 thousand cases. This number makes Indonesia ranks third highest for TB cases after India and China. However, the TB case finding rate in West Kalimantan has not reached the determined target of 152 per 100,000 population and even tends to decrease. In 2015 the Case Notification Rate (CNR) was 120 per 100,000 and in 2016 the CNR declined to 103 per 100,000. to increase community involvement, including students. This training aims to increase the knowledge and participation of Tanjungpura University students about tuberculosis so that it is expected to be an agent for the Pontianak City Health Office, especially in the detection of TB cases.

Keywords : Tuberculosis, students, Tanjungpura University, training, detection of TB Cases

\section{PENDAHULUAN}

Tuberkulosis paru merupakan penyakit infeksi menular yang disebabkan oleh Mycobacterium tuberculosis dan paling sering bermanifestasi di paru (Dinkes RI, 2002) Secara Global perkiraan insiden TB pada tahun 2016 terdapat 10,4 juta kasus insiden TB (CI 8,8 juta - 12 juta) yang setara dengan 120 kasus per 100.000 (WHO, 2017) lima negara dengan insiden kasus tertinggi adalah India, Indonesia, China, Philipina, dan Pakistan. Pada 2017, TB menyebabkan sekitar 1,3 juta kematian (kisaran, 1,2-1,4 juta) di antara orang HIVnegatif, dan ada 300.000 kematian tambahan karena TB (kisaran, 266 000335 000) di antara orang HIV-positif. 
Diperkirakan ada 10,0 juta kasus baru TB (kisaran, 9,0-11,1 juta), setara dengan 133 kasus (kisaran, 120-148) per 100.000 penduduk (WHO, 2018).

Penyakit TB di Indonesia merupakan masalah kesehatan yang harus ditanggulangi oleh pemerintah. Berdasarkan Survei Prevalensi Tuberkulosis tahun 2013-2014, prevalensi TB dengan konfirmasi bakteriologis di Indonesia sebesar 759 per 100.000 penduduk berumur 15 tahun ke atas dan prevalensi TB BTA positif sebesar 257 per 100.000 penduduk berumur 15 tahun ke atas. Sedangkan jumlah kasus TB tahun 2017 yaitu sebesar 420.994 kasus. Berdasarkan WHO Global TB Report 2018, diperkirakan insiden TBC di Indonesia mencapai 842 ribu kasus dengan angka mortalitas 107 ribu kasus. Jumlah ini membuat Indonesia berada di urutan ketiga tertinggi untuk kasus TBC setelah India dan China. Indonesia juga merupakan salah satu negara dengan persentase keberhasilan pengobatan TB MDR di bawah target dunia, yaitu hanya 51\% pada tahun 2017 (WHO, 2017). Data Riskesdas Indonesia menyatakan bahwa angka morbiditas kejadian tuberkulosis BTA (+) tahun 2014 sebesar 176.677 penduduk, tahun 2015 mengalami peningkatan menjadi 188.405 penduduk sedangkan tahun 2016 terjadi penurunan yang tidak terlalu signifikan 181.711 penduduk. Angka mortalitas tuberkulosis di Indonesia dari tahun 2014 sampai tahun 2016 cenderung mengalami peningkatan (Riskesdas, 2018).

Kota Pontianak adalah salah satu wilayah di Provinsi Kalimantan Barat dari 14 kabupaten/kota yang ada dan memiliki angka notifikasi kasus sebesar 138 per 100.000 penduduk pada tahun 2015 dan 131 per 100.000 pada tahun 2016, serta 77,19 per 100.000 pada tahun 2017 (Profil Dinkes Kota Pontianak, 2018). Ini artinya gambaran penemuan kasus $\mathrm{TB}$ di Kota Pontianak masih tinggi karena Case Notification Rate (CNR) di Provinsi
Kalimantan Barat adalah 120 per 100.000 pada tahun 2015 dan 103 per 100.000 pada tahun 2016 (Profil Dinkes Provinsi Kalbar, 2018). Pada tahun 2017, jumlah penderita TB paru BTA positif sebanyak 484 orang dari 285 orang yang ditemukan dari seluruh kasus TB.

Rencana Aksi Nasional Tuberkulosis Tahun 2016-2020 menghasilkan 6 (enam) strategi utama dalam program eliminasi TB. Salah satunya adalah meningkatkan kontribusi atau peran masyarakat dalam penemuan kasus TB. Hasil studi pendahuluan yang kami lakukan, baik berupa wawancara dengan pemegang progam TB di Dinas Kesehatan Kota Pontianak atau penelusuran data kasus TB di Kota Pontianak, elemen masyarakat belum dilibatkan secara aktif dalam program TB terutama dalam penemuan kasus, dikarenakan banyak masyarakat yang belum mengetahui mengenai gejala, pencegahan dan pengobatan penyakit TB.

Penelitian yang dilakukan di Medan oleh Harahap (2018) tentang perlunya partipasi berbagai pihak dalam program TB. Sementara itu, penelitian yang dilakukan oleh Fitriangga (2015) tentang pemberdayaan mantan penderita TB dalam meningkatkan angka penemuan kasus TB di Kabupaten Kubu Raya mendapatkan hasil bahwa mantan penderita dapat dilatiha untuk mendeteksi kasus TB dan mendampingi dalam masa pengobatan TB sehingga mantan penderita TB tersebut dapat dilibatkan dalam program $\mathrm{TB}$ di Kabupaten Kubu Raya.

Universitas Tanjungpura (Untan) merupakan satu-satunya universitas negeri dan perguruan tinggi terbesar di Provinsi Kalimantan Barat dengan jumlah mahasiswa aktif pada semester ganjil tahun 2018/2019 sebanyak 32.111 orang. Mahasiswa tersebut berasal tidak hanya dari dalam Kota Pontianak, ada yang berasal dari luar Kota Pontianak bahkan dari luar Provinsi Kalimantan Barat. Mahasiwa yang berasal dari luar Kota 
Pontianak atau dari luar Provinsi Kalimantan Barat tersebut, banyak yang bertempat tinggal di asrama mahasiswa yang disediakan oleh pihak Untan. Penghuni asrama merupakan populasi khusus yang merupakan salah satu populasi sasaran dalam program pencegahan penyakit $\mathrm{TB}$, karena penghuni asrama rentan terkena penyakit TB. Oleh karena itu, perlu diadakan pelatihan terhadap mahasiswa Untan tentang pentingnya mengenali tanda dan gejala TB sehingga dapat meningkatkan pengetahuan serta kesadaran mahasiswa Untan tentang penyakit TB.

\section{METODE PENERAPAN}

Persiapan yang dilakukan sebelum diadakannya kegiatan pelatihan ini adalah :

1. Melakukan koordinasi dengan pemegang program TB Dinas Kesehatan Kota Pontianak mengenai materi penyuluhan dan pelatihan TB bagi mahasiswa Untan.

2. Melakukan koordinasi dengan Badan Eksekutif Mahasiswa (BEM) di tiap fakultas yang ada di Untan untuk mengirimkan perwakilannya sebagai peserta dalam kegiatan penyuluhan ini.

3. Pembuatan materi penyuluhan TB dan pelatihan TB berupa cara skrining atau mengetahui gejala atau tanda-tanda khas penyakit TB.

4. Membuat kuesioner berupa pre dan post test yang diberikan kepada mahasiswa untuk menilai tingkat pemahaman mahasiswa mengenai penyakit TB untuk menilai efektivitas dari kegiatan penyuluhan ini.

5. Tindak lanjut peserta diminta untuk melakukan pelacakan kasus ke rumah warga yang teridentifikasi TB di sekitar lingkungan tempat tinggal peserta.
Tahap Penyuluhan

Kegiatan ini bertujuan untuk meningkatkan pengetahuan dan pemahaman mahasiswa di Untan mengenai penyakit TB, baik berupa gejala, pencegahan, serta pengobatannya sehingga mahasiswa diharapkan dapat termotivasi dalam meningkatkan kesadaran terhadap kesehatan dilingkungannya. Untan terdapat 9 (sembilan) fakultas, yaitu Fakultas Teknik, Fakultas Pertanian, Fakultas Sosial dan Ilmu Politik, Fakultas Ekonomi dan Bisnis, Fakultas Keguruan dan Ilmu Pendidikan, Fakultas Hukum, Fakultas Kehutanan, Fakultas Matematika dan Ilmu Pengetahuan Alam, serta Fakultas Kedokteran. Tiap fakultas mengirimkan perwakilan dari BEM sebanyak 10 orang sehingga terkumpul peserta sebanyak 115 orang peserta. Setiap peserta diberikan kuesioner untuk mengukur tingkat pengetahuan mahasiswa mengenai penyakit TB yang diberikan sewaktu sebelum materi penyuluhan (pre test) dan setelah materi penyuluhan (post test). Kuesioner ini berisi 10 pertanyaan terkait dengan gejala, pencegahan, pengobatan TB.

Sementara itu materi yang diberikan oleh narasumber dalam pelatihan ini antara lain mengenai situasi TB terkini di Indonesia, dan di Kota Pontianak khususnya oleh Kabid P3PL Dinas Kesehatan Kota Pontianak. Kemudian dilanjutkan dengan materi Penyakit Tuberkulosis oleh dokter Spesialis Paru dari RSUD Sultan Syarif Muhammad Al-Qadrie, terakhir materi tentang peran mahasiswa dalam program TB yang disampaikan oleh Kepala Departemen Kedokteran Komunitas Fakultas Kedokteran Universitas Tanjungpura.

Tahap Pelatihan dan Praktek Screening TB

Setiap perwakilan peserta dari tiap BEM fakultas yang hadir, diberikan kesempatan 
untuk melakukan latihan bagaimana melakukan screening TB dengan format yang telah disiapkan. Kemudian diakhir pelatihan, peserta diminta untuk berkomitmen untuk menerapkan pola hidup bersih dan sehat (PHBS) serta berkomitmen untuk melakukan pencegahan serta melakukan pendeteksian kasus TB dilingkungannya masingmasing.

\section{Tahap Tindak Lanjut}

Setelah dilakukan penyuluhan dan pelatihan ini, setiap peserta diminta untuk melakukan pelacakan kasus di sekitar tempat tinggal mereka yang diduga terdapat suspek TB. Setelah itu mereka diminta melaporkan kepada petugas puskesmas terdekat untuk ditindakanjuti oleh petugas puskesmas.

\section{HASIL DAN KETERCAPAIAN SASARAN}

Penyuluhan

Kegiatan penyuluhan dilakukan pada tanggal 16 November 2019 dengan jumlah peserta sebanyak 115 orang mahasiswa yang terdiri dari perwakilan BEM fakultas yang ada di Untan. Kegiatan dilakukan di Gedung Kuliah Bersama Lantai 3 Universitas Tanjungpura. Narasumber penyuluhan terdiri dari 3 (tiga) yaitu dari Kepala Bidang P3PL Dinas Kesehatan Kota Pontianak, dokter Spesialias Paru dari RSUD Sultan Syarif Muhammad AlQadrie Kota Pontianak, dan dari Kepala Departemen Kedokteran Komunitas Fakultas Kedokteran Universitas Tanjungpura.

Berikut ini adalah sebaran data karakteristik peserta pelatihan :

Tabel 1. Karakteristik Peserta Pelatihan

\begin{tabular}{|l|c|c|}
\hline Variabel & $\begin{array}{l}\text { Jumlah (n= 115 } \\
\text { orang) }\end{array}$ & Persentase \\
\hline Jenis Kelamin & 55 & 47,8 \\
Laki-laki & 60 & 52,17 \\
Perempuan & & \\
\hline Umur & 17 & 14,78 \\
20 & 15 & 13,04 \\
21 & 38 & 33,05 \\
22 & 33 & 28,70 \\
23 & 12 & 10,43 \\
24 & & \\
\hline Asal Daerah & 78 & 67,83 \\
Dalam Kota Pontianak & 37 & 32,17 \\
Luar Kota Pontianak &
\end{tabular}

Sumber : Data Primer, 2019

Mayoritas peserta pelatihan ini adalah perempuan dengan jumlah 60 orang $(52,17 \%)$. Umur peserta pelatihan ini paling banyak berumur 22 tahun sebanyak
38 orang $(33,05 \%)$. Peserta pelatihan ini kebanyakan berasal dari Kota Pontianak, yaitu sebanyak 78 orang $(67,83 \%)$.

Tabel 2. Distribusi Jawaban Benar Tiap Peserta dari Pertanyaan Pre Test Tiap Fakultas

\begin{tabular}{lccccccccc}
\hline Pertanyaan & $\begin{array}{l}\text { Teknik } \\
(\mathrm{n}=10)\end{array}$ & $\begin{array}{l}\text { Pertanian } \\
(\mathrm{n}=15)\end{array}$ & $\begin{array}{l}\text { Ekonomi } \\
\text { \& Bisnis } \\
(\mathrm{n}-=10)\end{array}$ & $\begin{array}{l}\text { Hukum } \\
(\mathrm{n}=10)\end{array}$ & $\begin{array}{l}\text { Kehutanan } \\
(\mathrm{n}=10)\end{array}$ & $\begin{array}{l}\text { Sospol } \\
(\mathrm{n}=15)\end{array}$ & $\begin{array}{l}\text { KIP } \\
(\mathrm{n}=10)\end{array}$ & $\begin{array}{l}\text { MIPA } \\
(\mathrm{n}=10)\end{array}$ & $\begin{array}{l}\text { Kedokteran } \\
(\mathrm{n}=15)\end{array}$ \\
\hline Definisi TB & 4 & 5 & 6 & 4 & 4 & 4 & 5 & 5 & 15 \\
Gejala Utama TB & 2 & 4 & 5 & 5 & 3 & 4 & 6 & 6 & 15 \\
Gejala Tambahan TB & 2 & 3 & 5 & 3 & 4 & 5 & 5 & 6 & 15
\end{tabular}




\begin{tabular}{|c|c|c|c|c|c|c|c|c|c|}
\hline Penularan TB & 3 & 6 & 6 & 4 & 4 & 3 & 5 & 6 & 14 \\
\hline $\begin{array}{l}\text { Orang dengan risiko } \\
\text { tinggi tertular TB }\end{array}$ & 4 & 5 & 6 & 3 & 5 & 4 & 6 & 7 & 15 \\
\hline Cara diagnosis TB & 7 & 5 & 5 & 4 & 2 & 3 & 5 & 6 & 10 \\
\hline Pengobatan TB & 3 & 6 & 5 & 5 & 2 & 3 & 4 & 6 & 11 \\
\hline Efek samping OAT & 3 & 5 & 5 & 5 & 3 & 3 & 5 & 7 & 15 \\
\hline $\begin{array}{l}\text { Risiko yang dialami } \\
\text { jika tidak patuh } \\
\text { berobat }\end{array}$ & 8 & 6 & 6 & 6 & 4 & 4 & 6 & 7 & 15 \\
\hline $\begin{array}{l}\text { Pencegahan } \\
\text { Penularan }\end{array}$ & 6 & 5 & 7 & 4 & 5 & 5 & 6 & 7 & 15 \\
\hline
\end{tabular}

Tabel 2 diatas menjelaskan tentang hasil jawaban benar tiap peserta pada tahap Pre Test. Dilihat dari Fakultas Teknik, dari 10 orang peserta, hanya pertanyaan no 6 dan 9 yang banyak dijawab benar dimana ada 7 (tujuh) orang peserta yang menjawab benar di pertanyaan no. 6 dan pertanyaan no 9 ada 8 (delapan) orang yang menjawab benar. Hasil yang sama juga didapatkan oleh fakultas yang lain. Sementara itu di Fakultas Kedokteran, hampir seluruh pertanyaan dapat dijawab dengan benar oleh peserta. Hal ini dimungkinkan karena memang mahasiswa sudah terpapar oleh informasi mengenai TB sebelumnya, baik melalui kuliah ataupun seminar yang pernah diikuti.

Tabel 3. Distribusi Jawaban Benar Tiap Peserta dari Pertanyaan Post Test Tiap Fakultas

\begin{tabular}{|c|c|c|c|c|c|c|c|c|c|}
\hline Pertanyaan & $\begin{array}{l}\text { Teknik } \\
(n=10)\end{array}$ & $\begin{array}{l}\text { Pertanian } \\
(\mathrm{n}=15)\end{array}$ & $\begin{array}{l}\text { Ekonomi } \\
\& \text { Bisnis } \\
(\mathrm{n}-=10)\end{array}$ & $\begin{array}{l}\text { Hukum } \\
(\mathrm{n}=10)\end{array}$ & $\begin{array}{l}\text { Kehutanan } \\
(\mathrm{n}=10)\end{array}$ & $\begin{array}{l}\text { Sospol } \\
(n=15)\end{array}$ & $\begin{array}{l}\text { KIP } \\
(n=10)\end{array}$ & $\begin{array}{l}\text { MIPA } \\
(n=10)\end{array}$ & $\begin{array}{l}\text { Kedokteran } \\
(\mathrm{n}=15)\end{array}$ \\
\hline Definisi TB & 10 & 10 & 9 & 8 & 9 & 12 & 10 & 10 & 15 \\
\hline Gejala Utama TB & 8 & 8 & 9 & 9 & 9 & 8 & 10 & 10 & 15 \\
\hline Gejala Tambahan TB & 8 & 9 & 9 & 8 & 9 & 10 & 10 & 10 & 15 \\
\hline Penularan TB & 9 & 10 & 10 & 9 & 8 & 10 & 10 & 10 & 14 \\
\hline $\begin{array}{l}\text { Orang dengan risiko } \\
\text { tinggi tertular TB }\end{array}$ & 8 & 8 & 10 & 8 & 8 & 10 & 8 & 10 & 15 \\
\hline Cara diagnosis TB & 9 & 8 & 8 & 8 & 8 & 10 & 8 & 7 & 15 \\
\hline Pengobatan TB & 8 & 8 & 9 & 8 & 7 & 7 & 8 & 8 & 14 \\
\hline Efek samping OAT & 9 & 9 & 10 & 8 & 7 & 10 & 8 & 7 & 15 \\
\hline $\begin{array}{l}\text { Risiko yang dialami } \\
\text { jika tidak patuh } \\
\text { berobat }\end{array}$ & 9 & 9 & 10 & 8 & 8 & 10 & 8 & 7 & 15 \\
\hline $\begin{array}{l}\text { Pencegahan } \\
\text { Penularan }\end{array}$ & 9 & 9 & 10 & 9 & 9 & 10 & 9 & 10 & 15 \\
\hline
\end{tabular}

Sebagian peserta dari tiap fakultas dapat menjawab pertanyaan kuesioner yang diberikan dengan benar, setelah mendapatkan materi mengenai penyakit TB. Hal ini sangat menggembirakan, artinya antusiasme peserta dalam mengikuti pelatihan ini sangat tinggi sehingga mereka memperhatikan dan akhirnya dapat menjawab seluruh pertanyaan dengan hasil yang memuaskan. Nilai rata-rata pre dan post test peserta berdasarkan tiap fakultas adalah sebagai berikut 


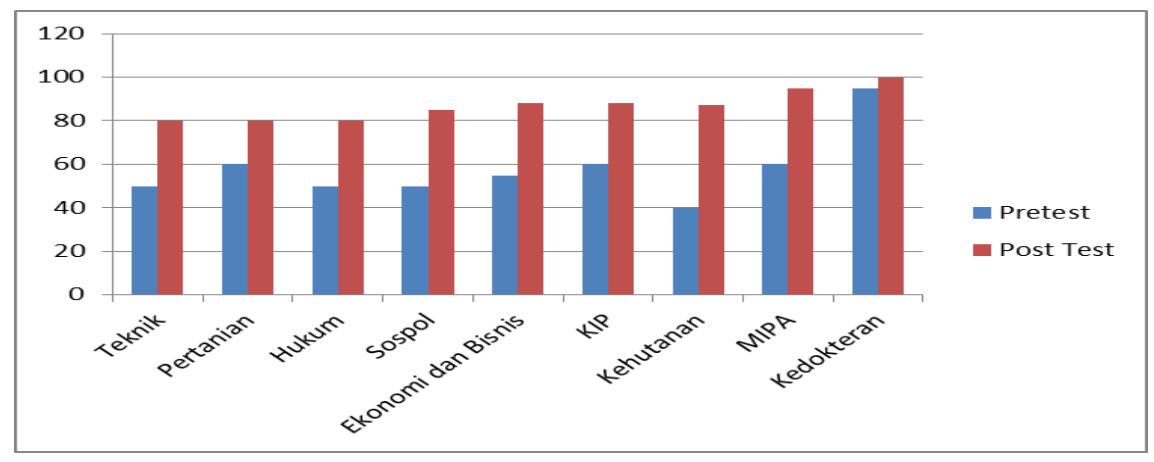

Gambar 1. Hasil Rata-rata Pre dan Post Test Tiap Fakultas

Dari hasil pengolahan data hasil pre dan post tiap fakultas, terdapat peningkatan pengetahuan dari peserta tiap fakultas. Peningkatan pengetahuan yang signifikan terdapat pada mahasiswa Fakultas Teknik dan Fakultas Pertanian. Hal ini menandakan bahwa tingkat partisipasi mahasiswa dalam pelatihan ini cukup baik, dan terbukti dapat meningkatkan pengetahuan tentang penyakit TB.

\section{Pelatihan Screening TB}

Peserta dari setiap perwakilan BEM Fakultas di Untan diminta untuk melakukan latihan bagaimana melakukan screening TB yang benar sesuai dengan format yang telah diberikan. Mulai dari cara menanyakan gejala dan penyakit TB hingga edukasi kepada peserta yang lain dan bagaimana meminta untuk dilakukan pemeriksaan lanjutan apabila ditemukan tanda-tanda mengarah ke penyakit TB.
Sementara itu dari hasil pelatihan melakukan screening terhadap peserta TB, terdapat 2 (dua) suspek TB yang berhasil diidentifikasi oleh peserta pelatihan TB dan disarankan untuk segera melakukan pemeriksaan dahak di puskesmas terdekat.

\section{Tindak Lanjut Penemuan Kasus}

Dari peserta penyuluhan dan pelatihan screening TB yang terdiri atas perwakilan 9 (sembilan) fakultas di Untan, tidak semua peserta berhasil melakukan atau menemukan kasus TB sampai batas waktu yang ditetapkan (maksimal sebulan setelah pelatihan). Peserta dari Fakultas Kedokteran yang berhasil menemukan masyarakat dengan gejala TB (suspek TB) dan mengirimkannya ke puskesmas untuk pemeriksaan lebih lanjut

.Tabel 4. Distribusi Penemuan Kasus TB oleh Peserta Pelatihan Tiap Fakultas

\begin{tabular}{|l|l|c|c|c|c|c|c|c|c|c|}
\hline No & Tugas & \multicolumn{7}{|c|}{ Fakultas } \\
\cline { 3 - 10 } & & Teknik & FEB & Pertanian & KIP & MIPA & Kedokteran & Sospol & Kehutanan & Hukum \\
\hline 1 & $\begin{array}{l}\text { Penemuan } \\
\text { suspek TB }\end{array}$ & 0 & 0 & 0 & 0 & 1 & 5 & 0 & 0 & 0 \\
\hline 2 & $\begin{array}{l}\text { Melaporkan } \\
\text { ke petugas } \\
\text { puskesmas }\end{array}$ & 0 & 0 & 0 & 0 & 1 & 5 & 0 & 0 & 0 \\
\hline
\end{tabular}

Dari tabel 4 diatas, dilihat hasil pelatihan ini dalam hal mahasiswa diminta untuk terlibat aktif dalam menemukan kasus TB disekitar lingkungan tempat tinggal 
mereka belum mendapatkan hasil yang memuaskan. Hanya mahasiswa dari Fakultas Kedokteran dan Fakultas MIPA yang berhasil mendeteksi kasus dan melaporkan kepada pihak puskesmas. Setelah kami melakukan evaluasi terhadap hasil pelatihan, ternyata terdapat miskomunikasi antara tim pengumpul data (mahasiswa FK Untan) dengan peserta dari fakultas lainnya sehingga hasil yang diharapkan dari pelatihan ini tidak optimal. Namun, hal ini tidak mengurangi nilai dari pentingnya pelibatan mahasiswa dalam program TB di Kota Pontianak. Karena melihat dari potensi yang ada, pelibatan masyarakat dalam hal ini mahasiswa sangat penting. Hanya memang perlu penguatan dan dorongan motivasi kepada mahasiswa untuk selalu meningkatkan kesadaran diri terhadap kesehatan pribadi dan lingkungan yang mungkin saja terpapar oleh TB.

Evaluasi secara umum yang kami lakukan, efektivitas peran mahasiswa dalam progam TB di Kota Pontianak perlu untuk ditingkatkan. Sesuai dengan RAN TB nasional 2016-2020 yang memang menyatakan bahwa peran masyarakat sangat penting dalam program TB. Oleh karenanya menindaklanjuti hasil dari pelatihan ini, dari FK Untan dan Dinas Kesehatan Kota Pontianak akan melakukan perluasan kerjasama dalam meningkatkan capaian program TB untuk mengeliminasi TB tahun 2030 dan eradikasi TB tahun 2050 di Kota Pontianak.

\section{KESIMPULAN}

Kegiatan penyuluhan dan pelatihan dalam melakukan screening TB bagi mahasiwa di Universitas Tanjungpura ini berjalan dengan baik dan dapat meningkatkan motivasi mahasiswa dalam terlibat aktif dalam program eliminasi TB di Kota Pontianak. Tindak lanjut dari kegiatan ini adalah akan dibentuknya Pusat Promosi dan Edukasi TB yang di inisiasi oleh Departemen Kedokteran Komunitas FK
Untan dan IMKU (Ikatan Mahasiwa Kedokteran FK Untan) bekerjasama dengan Dinas Kesehatan Kota Pontianak.

\section{UCAPAN TERIMA KASIH}

Terima kami ucapkan kepada Kepala Dinas Kesehatan Kota Pontianak serta Bidang Pemberantasan, Pencegahan Penyakit dan Penyehatan Lingkungan (P3PL) Dinas Kesehatan Kota Pontianak atas dukungan dalam kegiatan pengabdian masyarakat ini. Kami juga mengucapkan terima kasih kepada Dekan Fakultas yang ada dilingkungan Universitas Tanjungpura yang telah memberikan ijin kepada mahasiswa di fakultasnya untuk mengikuti kegiatan pelatihan ini.

\section{Daftar Pustaka}

Departemen Kesehatan Republik Indonesia, 2002, Pedoman nasional penanggulangan Tuberkulosis, 8th edition, Jakarta.

Fitirangga, Agus, M. Nasip, et al (2015). Pemberdayaan Mantan Pasien TB dalam Peningkatan Penemuan Suspek TB di Kabupaten Kubu Raya, Kalimantan Barat, Jurnal Pengendalian Penyakit dan Penyehatan Lingkungan Edisi 4 Desember 2014, hal. 1-7, ISSN 2089-290X,

http://repository.untan.ac.id/index.php?p =show_detail\&id=1146

J, Harahap, R. Amelia, et al (2018). Community Empowerment Program for Increasing Knowledge and Awareness of Tuberculosis Patients, Cadres, and Community in Medan City, Earth and Environtmental Science, doi : 10.1088/17551315/125/1/012102

Riset Kesehatan Dasar, 2018, Kementerian Kesehatan Republik Indonesia.

WHO, 2017. Global Tuberculosis Report 2017 Geneva.

WHO, 2018. Global Tuberculosis Report 2018, Geneva. 
Profil Dinas Kesehatan Kota Pontianak, 2018.
Profil Dinas Kesehatan Kalimantan Barat, 2018.
Provinsi 